\title{
FORESTRY AND WILDLIFE MANAGEMENT - DUAL ENDEAVORS ON FOREST LAND ${ }^{1}$
}

\author{
BY R. Y. EDWARDS, A. T. CRINGAN, C. D. FOWLE, R. C. PASSMORE, \\ A. J. REEVE and D. J. ROBINSON.
}

R. Y. Edwards, B.Sc.F. (Tor.), M. A. (Brit. Col.), is at present Biologist with the Parks and Recreation Division, B.C. Forest Service, Victoria.

A. T. Cringan, B.Sc.F. (Tor.), M. A. (Tor.), is a Biologist, Ontario Department of Lands and Forests, currently on loan to the Ontario Department of Agriculture at Guelph.

C. D. Fowle, B.A. and M.A. (Brit. Col.), Ph.D. (Tor.), is now Biologist in charge of Wildlife Research, Ontario Department of Lands and Forests, at Maple.

R. C. Passmore, B.Sc.F. (Tor.), is District Forester at Tweed, Ontario.

A. J. Reeve, B.Sc. (New Bruns.), is Chief, Forests and Game Section, Territorial Division, Northern Administration and Lands Branch, Department of Northern Affairs and National Resources, at Ottawa.

D. J. Robinson, B.A. and M.A.(Brit. Col.), is Game Biologist for Vancouver Island, with the B.C. Game Commission, at Nanaimo.

\section{ACKNOWLEDGEMENTS}

We are grateful to the following people for commenting upon this paper in its final form: R. H. Ahrens, B.C. Forest Service; J. F. Bendell, Queen's University; C. H. D. Clarke, Ontario Department of Lands and Forests; I. McT. Cowan, University of British Columbia; E. G. Oldham, B.C. Forest Service; and D. H. Pimlott, Newfoundland Department of Mines and Resources.

\section{ABSTRACT}

The main theme of the paper is that forest management influences the abundance of wildlife, and that wildlife is part of every forest. Forest management and wildlife management are inescapably linked by similar aims on the same land. The use of the forests for wood production is an imposed condition on wildlife managers, and the report shows by interesting examples the interplay of these two influences on the management problems of each.

\section{INTRODUCTION}

If this report serves to answer the question "Why does the Institute have a Wildlife Committee?" we shall be satisfied.

Wildlife management is a growing art and science in Canada. There are approximately one hundred university-trained wildlife biologists scattered across the country. In a number of cases their undergraduate training was in forestry or agriculture, but the majority obtained their first degree in Arts. Graduate degrees are the rule, with specialization in the wildlife field.

What is wildlife management? It is defined much as is forestry, except that it is directly concerned with vertebrate animals and their populations rather than with trees and forests. Wildlife management is the art and science of managing vertebrate populations to give the greatest benefit to man. It may ${ }^{1}$ A contribution from the Wildlife Committee of the Canadian Institute of Forestry. 
consist of rodent control in orchards, plantations or cities; of increasing deer for game, preserving deer for posterity, or reducing deer where they are causing damage. Its aims and activities are as varied as the kinds of animals within its sphere and as the many desires of man. It includes building elephant-proof fences in Africa, supervising the annual harvest of fur seals on stormy Pacific islands, combating hordes of rabbits with disease in Australia, and exterminating rat populations in the slums of large cities.

To say that wildlife management is concerned only with vertebrate animals and their populations is not correct, however. The forester is concerned with trees, but he must also know the environments in which trees are living. Without vegetation there can be no animals. The wildlife biologist must know vegetation to know animals; in forested regions he must know the forests to undertake his task of managing forest animals.

Animals, like trees, do not occur everywhere. Each species has a definite geographic range and occurs only in those parts of that range where ecological conditions are suitable. Nor do animals escape the influence of plant succession. Successions of vegetations are accompanied by associated successions of animals. This is true for moose, caribou and deer just as much as for smaller animals.

It need hardly be pointed out to foresters that since animals are dependent upon vegetation, and since their distribution and abundance change with plant succession, in a forested country like Canada the fate of the forests is a basic concern of wildlife management. Except in strictly agricultural areas in the Arctic barrens, and for strictly oceanic wildlife, there is no question of whether wildlife management and forestry interests are linked. Forest changes as a result of forestry could determine the activities of wildlife management over most of Canada. The question, therefore, is not whether wildlife management should co-operate with forestry-it has to-but whether forestry has anything to gain from wildlife management. Our task, then, is to examine the position of the forester in the most detail, for the wildlife biologist has no doubts about the need for more co-operation between the two fields.

Why are we concerned about co-operation? We hear much about wise resource husbandry, about the multiple-use of land to obtain maximum benefits, about conservation (used with a confusing variety of meanings), and about getting the most in the long run from wise use of natural wealth. The words are many but the deeds are few. If the words are empty, we should forget them. If there is truth in them, action is needed, and we can see no better start than combining the efforts of the two most important resource management endeavors over most of Canada, two fields with basically similar philosophies, for one, in its modern form, wildlife management, grew from the other, forestry.

In the many natural resource fields there are few people with sufficient time to consider land other than for their own narrow specializations in parts of the land, but most are aware of the "whole land". In spite of this specialization, we believe that most people concerned with any natural resource have an ethically superior concern for the future of all natural resources. Resources do not stand alone despite our insistence upon segregation in education, administration, management and utilization concerned with them. Better co-operation between forestry and wildlife management is not only desirable in itself, but 

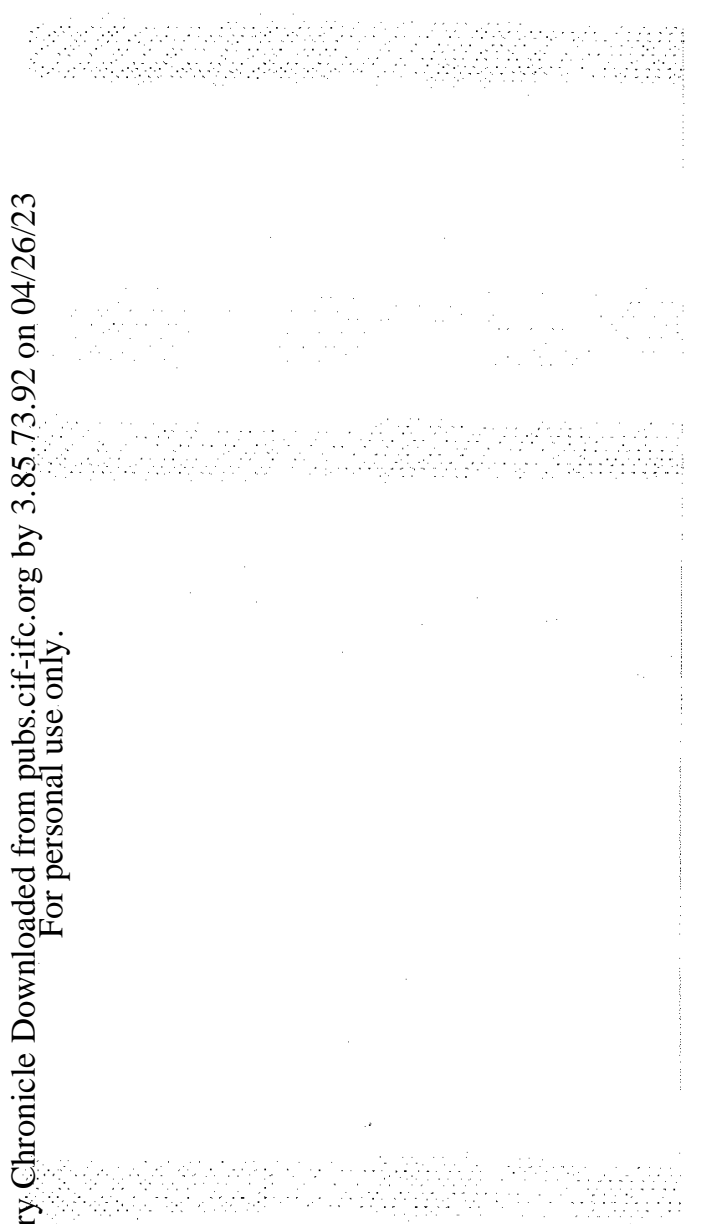

necessary as a demonstration of the sincerity of our often-repeated convictions regarding the wise management of land. If these two cannot work together and profit mutually from the association, most of the fine words we so often hear are transient dreams, not visions of a better future.

"Lip service to multiple use will not fool the public for long; they want sincerity and they want proof or performance" (Swift, 1947). "In other words, public demand for the best use of available natural resources will require multiple purpose management; best use of natural resources is multiple use" (Scott and Fowle, 1952).

\section{The Influence of Forestry Upon Wildlife and ITs Management}

Forest age is an important factor in the abundance of animals. There are more deer in North America today than at the time of Columbus, and the most important cause is the forest cutting which has removed mature forests and so created young forests with abundant food and cover for deer.

Fires and destruction of forests by insects may have had similar effects. The Interior of British Columbia has abundant moose over hundreds of square miles which had no moose thirty years ago. Fires in forests bordering dry Interior valleys created moose paradise, and they are thriving in willow, birch and aspen that replaced fir, spruce and cedar. In Newfoundland, moose have flourished since introduced there is 1878, again in 1904, and much of this success is due to pulpwood operations creating large areas of second growth forests.

Deer are abundant in the English River watershed in Northwestern Ontario since a recent outbreak of spruce budworm improved the habitat for deer by opening the canopy. In the Parry Sound and Kenora areas in Ontario it has been shown that increased control of forest fire through two decades has been an important factor contributing to declines in populations of deer (Passmore, MS.).

These gains were not made without losses. Caribou appear to require mature vegetations. Gains in deer and moose numbers have gone hand in hand with caribou declines and exterminations across Canada.

The fur industry has also had its gains and losses in our changing forests. The abundance of beaver and scarcity of marten today are two obvious trends.

Reforestation and fire protection are additional activities, controlled by foresters, which influence wildlife habitat. Any process which speeds plant succession speeds the succession of animals. Any process which perpetuates mature forests perpetuates animal species requiring these forests. One result of fire protection will serve as illustration. The care of vegetation in large parks usually falls to foresters. While fires are natural phenomena over much of Canada, there has been universal agreement that fire protection is necessary even in such "natural areas" as national and provincial parks. Some parks in Canada are world famous for their wildlife, and their establishment was due, in part, to the spectacular animals they contained. Most such parks were created before fire protection was effective, and when recent burns covered large areas. Their abundant wildlife was largely a result of fire having controlled vegetation in their favor. Fire protection since has been so effective that game ranges have decreased in size and quality in a number of important games areas. 
Forestry, operating without concern for wildlife, may have an influence on wildlife which is so nearly absolute that wildlife management can operate only within narrow limits which forestry unknowingly imposes. The decline of wildlife in some parks is due to forest policy. No amount of good wildlife management without co-operation from forestry can do much to change the present trend. Abundant deer and blue grouse on Vancouver Island are not the result of wildlife management. They are the result of forestry. Similarly, the length of time that these ranges remain productive of game depends mainly on the success of forestry in creating a new forest.

The principle illustrated is nearly absolute. Forest animals, from trout to grouse, from mice to moose, flourish in relation to forest conditions, and wildlife management on forest land can operate only within narrow limits if it works alone. This is nor a complaint; it is a statement of fact basic to the theme at hand. Wildlife management must work with forestry if it is to realize more than a small part of its potential.

With this fact established, foresters may wonder what wildlife management has to offer them. The remainder of this report is devoted to this question.

\section{Damage to Forests Because of Wildlife}

Canadian foresters are only beginning to see and be concerned about wildlife damage to trees, consumption of seed by rodents and related problems. As our forestry methods become more intensive, our concern over these continuous drains on forest establishment and growth will increase. This prediotion is based upon trends observable in the forestry literature by anyone and upon the increasing interest of North American foresters in browse damage, seed consumption, girdling and related natural processes occurring in forests where rapid production of wood is the essence of forestry. These are detrimental effects of wildlife upon the practice of forestry. As a result they indicate where wildlife management can benefit forestry.

Inadequate regeneration of new forests is a chronic problem across Canada. From coast to coast millions of rodents are consuming seeds and assuring the continuity of the problem. In our southern hardwoods direct seeding of walnut, oak and hickory may be impossible due to squirrels (Toumey and Kors tian, 1947). The problem is not confined to these species. In ponderosa pine stands squirrels may remove up to $89 \%$ of the seed crop (Squillace, 1953). In the humid forests of the Pacific Coast "direct seeding of Douglas fir is out of the question" because of Peromyscus, the deer mouse (Garman and OrrEwing, 1949). The same mammal affects the success of direct seeding in burned and cut-over lands in Ontario (Leslie, 1953).

Once established, a young forest is subject to several forms of damage from a variety of wildlife species. This damage can be considerable. Deer browsing has destroyed a pine plantation in Ontario (Stiell and Farrar, 1953), and part of a plantation in British Columbia (McQuillan, 1955). A thorough and extensive survey in Wisconsin has revealed that deer browsing is killing a fifth of all natural regeneration of commercial tree species in that State. In one area involving parts of five counties the loss was 60\% (DeBoer, 1947; Swift, 1948). 
Some Pacific Coast foresters are presently concerned over increasing damage by black bears, which strip away bark and eat cambium in the spring. One paper reports up to $25 \%$ of a Douglas fir stand dead or damaged (Scheffer, 1952). Another predicts a loss of 400 million bd. ft. in 40 years (Merrill, 1953).

Buckland (1952) reports squirrels girdling western hemlock in British Columbia with damage extending over 6000 acres. The porcupine problem in eastern Canada has received wide publicity. Krefting (1953) reports that young jack pines protected from hares had $2 \frac{1 / 2}{2}$ times the growth of unprotected seedlings. A forest is more than trees, and its many components have little regard for the wishes of man.

Damage by beaver can be cause for concern. Beaver may flood superior growing sites or inundate roads. Culverts may be dammed with wonderful persistence. Their local logging activities can assume economic proportions. In some cases these expensive activities may be more than offset by benefits received from this remarkable animal. It may require a Solomon to establish whether the balance sheet finishes red or black for a given situation.

More examples could be given but these will suffice. They show that wildlife can create problems in forestry, and that the damage can mean fewer dollars from crops of wood which may be uncertain enough as to future profits in any event. While these are forestry problems because they affect the productivity of forests, their solutions lie with wildlife management, yet undoubtedly most such situations require the attention of both.

Organizations engaged in forestry face another potential loss which is indirectly due to wildlife. Forest roads often provide access into otherwise inaccessible areas. Cutting can increase some wildlife species, game species included. The result may be an attraction to the public, hunters and fishermen mainly, who wish to use such lands, pursuing wildlife which is a public re source, on lands which are public lands, and sometimes over roads which were built with public funds. The result can be expensive in damaged roads, bridges and equipment, pilfered supplies, damage to regeneration, increased fire haz ards, and increased public liability. These are real problems facing government and industry in Canada today. The solution can lie only in co-operation by those concerned. There are good examples, on Vancouver Island among other places, showing that this method works. Solutions may be sought by foresters rather than just conceded by them as necessary. Much of the human traffic may be seeking game which good silviculture requires to be reduced in numbers. Even in the absence of silvicultural need, the hunting and fishing public have certain rights over such lands; foresters will be the first to agree that a resource unused can be a resource lost, and that such loss should not be tolerated where it can be prevented.

Companies with large operations are currently facing the problem of increased demands for recreational use of their lands. Rapid strides have been made, and the result is one of the major advances in the multiple use of wild land that has taken place in recent years. In 1955 K. A. Adams, Public Recreation Administrator, Weyerhaeuser Timber Company told the Society of Ameri can Foresters, "Most of us are aware that the Stanford Research Institute has predicted that the Nation's need for timber products will increase about 25 
per cent by 1975 . But did you know that the Public Affairs Institute has said that the demand for recreation by 1960 will be 36 per cent above last year and by 1965 will be 75 per cent greater?

"Where will the public go in future while on this recreational spree? National parks and forests? Yes, but facilities there were crowded this year. It is evident that more and more pressure will be placed on the private land owner to open his lands.

"Something's gotta give!

"Since the end of World War II, Weyerhaeuser Timber Company has opened increasing amounts of its Oregon and Washington timber land to the recreation seeker. During the current deer hunting season, essentially all of its two-and-a-half million acres that are not in operating areas bear the "Hunters Welcome" sign. Roughly half of the Company's roads are open to hunter vehicle travel.

"On several of these tree farms, foresters provide free coffee and lodging facilities for visiting hunters.

"The company also maintains 11 public parks on its streams or lakeside in the two states. Each offers piped running water, sanitary facilities, picnic benches and tables, fire places and free firewood.

"During the year, Company lands are visited by more than $50,000 \ldots$ (recreation seekers of many kinds)."

At least one Canadian company is using similar methods on an experimental basis. On Vancouver Island, MacMillan and Bloedel Ltd. open their roads to the public (Anon. 1955): "In the course of this co-operative arrangement, within the past 12 months, the Company has counted 2,674 hunters into a portion of the cut-over land, plus 675 fishermen to one stream and its tributaries in the spring of 1955 . Berry pickers and campers were in addition estimated at 1,300 .

"The total travellers into Forest Management Licences 20 and 21 in one season are conservatively estimated to be 6000 to 7500 . The trend appears to be rapidly upward."

Successful use of forest land for recreation as well as for growing trees requires the joint efforts of foresters and wildlife biologists. Most wildlife work involves close contact with sportsmen who are often well organized into clubs, and these are the focal points of efforts to obtain public co-operation. This land use problem is growing lustily across Canada. Its solution can be relatively simple if approached co-operatively by foresters, biologists and the public.

\section{Direct Beneftrs From Wildlife to the Forests}

Little is known about direct benefits from wildlife to forests. While damage, though serious, is seldom obvious, benefits are usually still more obscure. There is a principle involved in the fact that the insect which destroys forests is more obvious than the parasite which prevents such destructive outbreaks.

In the early 1900s there was much said about the value of birds for saving farm and forest from the insect horde. The statements were based on large quantities of insects found in bird stomachs. If the investigators had looked at the abundance and fecundity of insects left in farm and forest, they 
might have made more cautious statements. The modern trend is to be more careful, and in some cases to deny the birds any usefulness in this regard (Dowden et al, 1953; Kendeigh, 1947). Complete facts probably have yet to appear. Large numbers of birds and insect-eating small mammals in our forests may be more valuable than suspected. Much of their value may be in preventing outbreaks. The inability of birds to stop an insect horde in full spate may be akin to the fire crew helpless at a big fire pushed by wind. Both, however, may be able to prevent extensive damage by early action in localized trouble spots. Hungarian foresters put nesting boxes for birds in their forests, and may have good reasons for doing so. (Personal communication from M. D. Udvardy; see also Hamerstrom, 1954, concerning bird boxes used by German foresters.) When our smallest mammals, the shrews and mice, can destroy $50 \%$ to $80 \%$ of the prepupae of larch sawfly (Graham, 1928) the figures look significant. More recently Holling (1954) showed that small mammals destroyed 40 per cent of cocooned sawflies in a pine plantation in a year of low abundance for these mammals. In future, man's plans for the natural control of forest insects may have wildlife management playing its part.

Sometimes it is possible to turn apparent losses into gains. Wildlife species are selective in their foods. In many cases these preferences are known to have changed the species composition of forests. Manipulation of wildlife populations is a possible way to eliminate undesirable plant species from young forests, and perhaps even to do some pruning. A similar use of wildlife is noted by Squillace (1953) for improving the genetic quality of ponderosa pine regeneration. Since seed consumption by squirrels may be high (up to $89 \%$ ), selection of superior phenotypes as seed trees, and making their trunks unclimbable by simple metal devices, can ensure that seed for the next crop is of superior quality.

Beaver can be of high value. Their influence upon stream flow and water tables can improve sites, and their water reservoirs are often of major importance in fire protection. The relative ease with which beavers and their works are controlled adds to these values.

\section{Forest Publicity and WILdLIFE}

Good public relations are desirable to any industry. Forestry is no exception. Fire prevention campaigns have been based largely upon publicity via posters, blotters, speeches, movies, radio, magazine advertisements and similar media for reaching the eyes, ears and heart of the public. Wildlife has figured strongly in these campaigns. It is not easy to get emotional over trees, but put a fawn by a charred stump and all the elements of "human interest" are present. This approach has been so widely and repeatedly used that some shop wear might be expected, yet variations on the same theme are still appearing in fresh ink, presumably because it still gets the message across.

A new theme with a similar approach has appeared in recent years. $\mathbf{A}$ large American forest products company has full-page ads in national magazines advertising its good conservation through tree farming. Each ad has a colored picture featuring wildlife, not tree farms. The trees are in the background.

If this approach to forestry publicity has value in words and pictures, it 
must have more value on the land. Foresters have no more logical or easily available method of improving public sympathy toward their tasks than to aid and even encourage, on forest lands, those aspects of wildlife management which contribute to the recreational enjoyment of the public.

\section{ECONOMIC AND SOCIAL BENEFITS}

The seasonal nature of most forestry work in Canada has its disadvantages. Equipment may get only seasonal use, and good men in seasonal jobs are not easily obtained year after year. Integration of forestry and wildlife management programs can partly solve these problems as shown by some government organizations, notably in Ontario (Scott and Fowle, 1952). Good organization and good planning can ensure that there are adequate men and equipment for the management and utilization of these two resources. There may also be better men and equipment at the same time because of their double need.

Trapping can contribute to the solution of employment problems. There are forestry jobs in the summer months, as on protection crews, in lookouts, and trapping in intervening months can assure year round income. Guiding, packing and providing other services to tourists and hunters can be additional factors stabilizing the seasonal working force. Such integrated employment arrangements operate in many parts of Canada today, but are largely fortuitous where they occur. Efforts to encourage and aid this integration would result in increased benefits to all concerned.

These employment problems have their social aspects. We are concerned with resources because we are concerned with people and their welfare. To ignore social benefits would be to ignore some of the most important aspects of the theme at hand.

Industries based on our forests are dependent upon a body of people whose collective efforts turn the wheels of production. Some live in isolated communities, and the trend for those working in the forest is to live in "company towns". A stable working force is a boon to any industry. A stable working force is composed of people, contented people we suppose, who see no reason to be on the move. The stable worker is a good worker - and a happy worker.

A study of recreation in industry, conducted in Ontario (Anon., 1951), indicates that 97 per cent of all companies considered recreation for employees to have value. Large and presumably successful companies were all convinced of its value. The general opinion of these companies was - "We believe that our human resources benefit from recreation, and so we believe that recreation increases production."

We have noted that wildlife can play its part in providing off-season employment to forest workers. The role of wildlife in benefiting forest workers does not end there. People must play. The form of play or recreation that they choose can be destructive or beneficial to a successful life. A stable working force in an isolated community can be such only if its people like their environment, and most of their recreation must be found in or near that environment.

North Americans like to hunt and fish. There are many facts and figures to prove this, but suffice it so say that in the State of Washington one person in six buys a hunting or fishing license (Walliace, 1952). Populations in large cities 
undoubtedly affect such figures; in forest communities the proportion must be higher.

Game and fish management on forest lands has an important social benefit to offer forest industry. The public, which forest roads and abundant game can lure onto managed forest lands, is composed in part of forest workers. They are finding there the recreation important to successful and happy living.

The potential benefits from this relationship between the two resources are greater than the present picture indicates. The wildlife is there and, over much of Canada, underused. It remains for industry to see this potential, and then realize it through public relations and wildlife management compatible with forest policies.

\section{Thie Monetary Value of Wildlife to Forestry}

Time is a major element in forestry. Fifty to a hundred years is not long in a growing forest, but it is a long time to wait for financial returns. Resulting difficulties need no explanation to foresters.

Fortunately, a forest is more than trees. There are other uses for forest land besides wood production. Financial worries over the time element in growing merchantable timber are greater for people who consider only trees, than for those who see forest land with its continuous benefits from water, fish, game, fur, recreation and grazing.

Monetary evaluations of forest wildlife are few. Aside from fur, the full value of wildlife is difficult to express. There are social values involved which, so far at least, defy adequate evaluation. Some monetary evaluations are available, however, and are useful as long as their limited bases for calculation are kept in mind.

Tentative calculations of the potential gross business value of wildlife in northwestern Ontario, based on the value of the fur catch and the money spent by sportsmen, shows a total value of up to $\$ 135$ per square mile per year. The value of deer alone might reach $\$ 84$ per square mile. These figures apply to large areas, and small areas may be better. The operator of a successful hunting camp in eastern Ontario calculates that he receives from deer hunters $\$ 900$ per square mile per year from the hunted area surrounding his lodge. These figures are not meant to indicate the value of game, but rather to show the order of income possible from catering to the hunting public-

The fur industry is still important in Canada. Ontario has about 12,000 trappers. British Columbia has 6,000, Manitoba 8,000. Much of their fur comes from forest lands, and has noteworthy value. Peterson and Crichton (1949) calculate that fur production in the Chapleau Forest District of Ontario is worth $\$ 16.86$ per square mile annually. A similar calculation for Sioux Lookout Forest District in Ontario indicates an annual value of $\$ 15.36$ per square mile (Cringan, MS). Trap lines about Fort Nelson, British Columbia, produced $\$ 15.15$ per square mile per year over a twenty year period (Edwards, unpub. thesis, 1950). Cowan (1955) has calculated that the value of fur from Manitoba and Ontario was about $\$ 13$ per square mile in 1952 , a year of low fur value. In the fiscal year ending March 31, 1954, fur harvested in Manitoba had a value of over $\$ 1,600,000$, or a value per square mile of $\$ 6.58$ over the whole province (Reeve, MS). 
These figures may look low to foresters. Remember, however, that they are annual figures, and if allowed to accumulate over periods of years approximating rotation periods, even at low interest rates, they assume impressive proportions.

Wildlife and its management have an important business role to play on forest lands. Neither governments nor forest industries can afford to ignore their value.

\section{Conclusion and Summary}

The main themes of this paper can be briefly stated. They are that forest management itself influences the abundance of wildlife, and that wildlife is a part of every forest, affecting all phases of its management. These effects can be detrimental or beneficial to the aims of forestry, whether socially, biologically or economically. Just as forestry seeks increased benefits for man from trees, wildlife management seeks increased benefits from wildlife. These two endeavors are inescapably linked by similar aims on the same lands. Only the emphasis is different in each case. It is obvious, we think, that these two professions must work together in order that each achieves its aims.

Once foresters were few and employed by governments. This is largely true of wildlife managers today. The forest industries have already begun to recognize their interest in wildlife, however. The problems are widespread and diversified enough to ensure that this trend will continue. The results will be more economical forestry, and more benefits from wildlife.

When foresters are faced with small mammals preventing regeneration, or deer ruining established regeneration, there is room for more co-operation. When hunters crowd logging roads and fishermen carry off tractor parts, there is room for more co-operation. When mills damage fishing waters, and logging methods unnecessarily ruin game ranges, the need for more co-operation is as urgent for forestry interests as for the public if good public relations are desirable.

The need for more understanding and co-operation is obvious from an increasing quantity of evidence. That is why there is a Wildlife Committee in the Canadian Institute of Forestry.

\section{REFERENCES}

ADAMS, K. A. 1955. Hunters pose management task. Western Conservation Jour. 12(5): 20-22; 36-39.

ANON. 1951. Recreation in Industry. Ont. Dept. Education. 46 pp.

ANON. 1955. Brief submitted to Royal Commission on Forestry, British Columbia, by MacMillan and Bloedel Limited. November 3, 1955. Vancouver.

BUCKLAND, D. C., and E. G. MARPLES. 1952. Rodent damage to western hemlock. For. Chron., 28 (2): 25-30.

COWAN, I. McT. 1955. Wildlife conservation in Canada. Jour. Wildl. Manag., 19:161-176. DE BOER, S. G. 1947. The deer damage to forest reproduction survey. Wisc. Conserv. Dept. Publ. No. 340.

DOWDEN, P. B., H. A. JAYNES and V. M. CAROLIN. 1953. The role of birds in a spruce budworm outbreak in Maine. Jour. Econ. Entomol., 46:307-312.

GARMAN, E. H., and A. L. ORR-EWING. 1949. Direct seeding experiments in the southern Coastal Region of British Columbia. 1923-1949. B.C. For. Ser. Tech. Bull. T31. 
GRAHAM, S. A. 1928. Influence of small mammals and other factors upon larch sawfly surviral in the Lake States. Jour. Econ. Entomol. 21:310.

HAMERSTROM, F. 1954. Revicw of Bird Box Manual for Forest Protection by Otto Henze, 1949. 2nd ed. Staatiche Vogelschutzwarte Garmisch-Partenkirchen. 122 pp. Jour. Wildl Manag., 18:272.

HOLIING, C. S. 1954. The selection by Sorex cinerews cinereus Kerr, Blarina brevicanda tal paides Gapper and Peromyscus maniculatus bairdii Hoy and Kennicost of healthy, dead and parasitized cocooned larvae of the sawfly Neadiprion sertifer Geoff. Unpub. thesis, Unit. of Toronto.

KENDEIGH, S. C. 1947. Bird population studies in the coniferous forest biome during a sproce budworm outbreak. Biol. Bull. No. 1. Res. Div., Ont. Dept. Lands and Forests.

KREFTING, L. W. 1953. Snowshoe hare damage to a jack pine plantation in Minnesota. Gt Lakes Expt. Sta. Tech. Note No. 402.

LESLIE, A. P. 1953. Direct seeding as a means of reforestation. Pulp \& Paper Magazine of Canada, 54(5):180-188.

MCQUILLAN, D. 1955. Trends in reforestation. Summary of papers given in panel discression. C.I.F., V.I. Section, Sept. 30, 1955. Mimeo.

MERRILL, A. H. 1953. Bears hamper tree growth in California. Jour. For., 51:928-929.

PETERSON, R. L., and V. CRICHTON. 1949. The fur resources of the Chaplean District, Ontario. Can. Jour. Res., D27:68-84.

SCHEFFER, T. H. 1952. Spring incidence of damage to forest trees by certain mammale. Murrelet, 33:38-41.

SCOTT, D. R. M., and C. D. FOWLE. 1952. The correlation of silvicultural systems and wildlife management. For. Chron. $28(4): 79-84$.

SQUILLACE, A. E. 1953. Effects of squirrels on the supply of ponderosa pine seed. Northern Rocky Mtn. For. and Range Expt. Sta., Res. Note No. 131.

STIELL, W. M., and J. L. FARRAR, 1953 Browse damage by deer in a pine plantation. Canad. For. Br. Silvic. Lft. No. 83.

SWIFT, E. 1947. Wildlife as a forest crop in the Lake States. Proc. Soc. Am. For., 1947: 483-492. SWIFT, E. 1948. Wisconsin's deer damage to forest reproduction survey. Wisc. Conserv. Dept Publ. No. 347.

TOUMEY, J. W., and C. F. KORSTIAN. 1942. Seeding and planting in the practice of forestry. John Wiley and Sons. N.Y.

WALLACE, R. F. 1952. Economic aspects of wildlife resources of the State of Washington State Coll. of Wash. Press. Economic and Business Studies, Bull. Na. 19. 